from the surface waters by a layer within which the density increased so rapidly with depth that it had the character of a discontinuity layer and within this layer there was a distinct salinity maximum. The discontinuity layer or thermocline covered the whole area of the survey and showed a slight slope to seawards.

The water masses above the thermocline showed a small and irregular vertical temperature gradient, but within the thermocline itself, the gradient was very marked-about $9 \mathrm{deg}$. C. in 13 fathoms off the coast of Sierra Leone, and about $4 \mathrm{deg}$. C. in 5 fathoms off Ghana. The salinity gradient was most pronounced in the surface waters, especially near the coast. On proceeding away from the coast, the salinity of the surface waters increased rapidly, and at the same time the temperature decreased. Off the coast of Ghana, however, this tendency was reversed, presumably as a result of upwelling near the cosst. In this region, colder and more saline water was found close to the surface inshore, and as a result the thermocline had a smaller vertical extension than elsewhere in the area of the survey.

Table 1. AVERAGR DEPTH OF THE THERMOCLINB OFF THE COAST OF THE BRITISH WEST AFRICAN TERRITORIF

\begin{tabular}{|l|c|c|c|}
\hline \multicolumn{1}{|c|}{ Coast } & $\begin{array}{c}\text { No. of } \\
\text { stations }\end{array}$ & $\begin{array}{c}\text { Average depth from surface } \\
\text { Bottom of } \\
\text { surface water } \\
\text { (fathoms) }\end{array}$ & $\begin{array}{c}\text { Bottom of } \\
\text { thermocline } \\
\text { (fathoms) }\end{array}$ \\
\hline $\begin{array}{l}\text { Gambia } \\
\text { Sierra Leone }\end{array}$ & 12 & 10 & 24 \\
Ghana & 10 & 12 & 28 \\
Nigeria & 16 & 15 & 15 \\
\hline
\end{tabular}

The average depth of the thermocline is indicated in Table 1. It will be seen that the bottom of the surface water approximates to that depth (10 fathoms) at which Postel and Salzen observed the change from euryholine and eurythermal species to predominately marine. This suggests that the thermocline probably plays some part in determining the nature and distribution of the inshore fish fauna of West Africa. Unfortunately, the results of the 1952 hydrographic survey are insufficient to allow any precise relationships to be determined, but in view of the fact that the thermocline is a constant and widespread feature of the waters on the West African shelf, its presence should, perhaps, be considered as a contributory cause of the correspondence between the Tema area and the French Guinea shelf.

$$
\text { J. C. D. Watts }
$$

Fisheries Development and Research Unit, Freetown.

Dec. 31.

2 Salzen, E. A., Nature, 178, 1105 (1956).

${ }^{2}$ Postel, E., Cons. Internat. Explor. Mer, Rxpp. et Proc.-Verb., 137, 10 (1955).

3 Defant, A., Deutsche Atlantische Exped., Meteor, 1925-27, Wiss. Erg., B, No. 1, 289 (1939).

\section{Bixbyite from Nagpur}

DURING an examination of polished sections from Prof. A. M. Bateman's collection of Indian manganese made during his trip in 1954 (1232a, Joda East Nagpur), I noticed a few grains of a greyish white mineral with a distinct yellow tint and a slightly greater hardness than braunite, with which it is associated. Etch tests with nitric acid, potassium cyanide, stannous chloride and hydrogen peroxide were negative. Microchemical tests indicated the

\begin{tabular}{crcccccc}
\multicolumn{7}{c}{ Table 1} \\
$d$ & $I$ & $d$ & $I$ & $d$ & $I$ & $d$ & $I$ \\
$4 \cdot 52$ & 1 & $2 \cdot 14$ & 6 & $1 \cdot 49$ & 1 & $1 \cdot 10$ & 2 \\
$3 \cdot 34$ & 1 & $1 \cdot 87$ & 1 & $1 \cdot 46$ & 2 & $1 \cdot 14$ & 1 \\
$3 \cdot 19$ & 2 & $1 \cdot 80$ & 2 & $1 \cdot 40$ & 8 & 1.07 & 8 \\
$2 \cdot 98$ & 1 & $1 \cdot 71$ & 1 & $1 \cdot 35$ & 2 & 1.05 & 7 \\
$2 \cdot 73$ & 10 & $1 \cdot 66$ & 9 & 1.25 & 1 & $1 \cdot 03$ & 2 \\
$2 \cdot 33$ & 4 & $1 \cdot 53$ & 2 & $1 \cdot 17$ & 1 & &
\end{tabular}

$d$, Spacings in Angstrom units; $I$, estimated intensities

presence of manganese and iron. X-ray photographs of the mineral were taken by the Debye-Scherrer method using iron $K$ radiation. The $d$ spacings observed from the film, as given in Table 1, agree fairly well with the values obtained by Fleischer and Richmond ${ }^{\mathfrak{l}}$ for bixbyite from the Thomas Range in Utah.

Fleischer and Richmond give the formula $(\mathrm{Mn} / \mathrm{Fe})_{2} \mathrm{O}_{3}$ for bixbyite. Mason ${ }^{2}$ has shown the chemical similarity and structural identity of bixbyite and sitaparite.

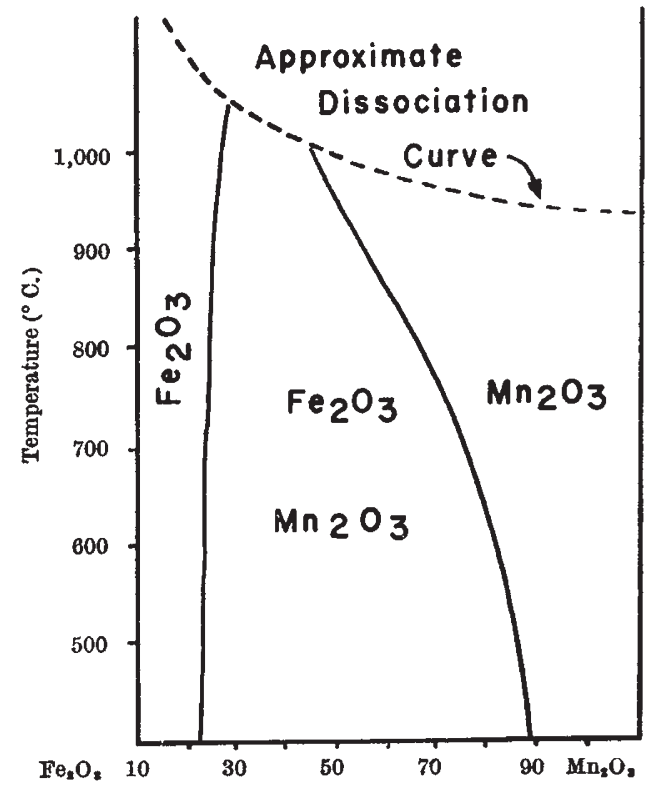

Fig. 1. The system $\mathrm{Fe}_{2} \mathrm{O}_{3}-\mathrm{Mn}_{2} \mathrm{O}_{\mathrm{a}}$ (after Mason, Amer. Mineral.

Fig. 1 indicates that the solubility of $\mathrm{Fe}_{2} \mathrm{O}_{3}$ in $\mathrm{Mn}_{2} \mathrm{O}_{3}$ increases with increasing temperature.

Bixbyite formed at high temperatures contains 45-60 per cent $\mathrm{Fe}_{2} \mathrm{O}_{3}$. Sitaparite formed during metamorphism of manganese ores contains about 30 per cent $\mathrm{Fe}_{2} \mathrm{O}_{3}$. Unmixing of these minerals into iron-poor sitaparite and iron-rich bixbyite has significance in geological thermometry.

Bixbyite has been reported from many locolities including Patagonia, Sweden, South Africa, Utah and New Mexico. A survey of the literature shows that this is the first report of the minersl from India.

The above observations were made during a study of Indian manganese ores at the Laboratory of Economic Geology, Yale University.

I am grateful to Prof. Alan M. Bateman for his direction and valuable help.

\section{B. L. Sregentvas}

Laboratory of Economic Geology,

Yale University,

New Haven, Conn.

${ }^{2}$ Richmond, W. E., and Fleischer, M., Econ. Geol., 38, 269 (1943).

Mason, B., Amer. Mineral., 29, 66 (1944) 